Polonia JOURNAL

\title{
COSMOPOLITANISM, MIGRATION IN VIEW OF KRZYSZTOF KIESLOWSKI'S IDEALISM
}

\author{
KOSMOPOLITANIZM, \\ MIGRACJE W ŚWIETLE IDEALIZMU \\ KRZYSZTOFA KIEŚLOWSKIEGO
}

\begin{abstract}
ABSTRAKT
W artykule Kosmopolitanizm, migracje w świetle idealizmu Krzysztofa Kieślowskiego Janina Falkowska przygląda się pojęciu „kosmopolityzm” w kontekście późnych filmów Krzysztofa Kieślowskiego. Biorąc pod uwagę idealistyczne założenia kosmopolityzmu i jego późniejsza „degeneracje” w kierunku kolonialistycznego spojrzenia na „innych”, autorka szczegółowo analizuje film Biały Kieślowskiego, który ujawnia wewnętrzne sprzeczności i niejasności w idealistycznym podejściu do idei kosmopolityzmu i równości.
\end{abstract}

Słowa kluczowe: kosmopolityzm, migracje, Krzysztof Kieślowski, równość, kolonializm 


\begin{abstract}
In the article "Cosmopolitanism, migration in view of Krzysztof Kieslowski's idealism" Janina Falkowska explores the idea of cosmopolitanism in the context of Krzysztof Kieslowski's last films. She takes into consideration the idealistic tradition of cosmopolitanism and its later "degeneration" in the direction of the colonialist perspective; the author analyzes the film Bialy (White) which reveals internal contradictions and ambiguities in its idealistic approach to the ideas of cosmopolitanism and equality.
\end{abstract}

Keywords: cosmopolitanism, migration, Krzysztof Kieslowski, equality, colonialism

The idealistic idea of Cosmopolitanism implies that we are all "citizens of the world" after Immanuel Kant who alleged that all human beings are equal members of a universal community.

Cosmopolitanism in the context of migration may be understood as a shift or transition to a community to which the newcomers want to belong and to which they aspire. In many cases the countries of migrants' dreams are supposedly democratic and open-minded, the societies which are based on an inclusive morality, a shared economic relationship, or a political structure that encompasses different nations. In a cosmopolitan community, individuals from different places (e.g. nation-states) form relationships of mutual respect. Kwame Anthony Appiah, for instance, suggests the possibility of "a cosmopolitan community in which individuals from varying locations (physical, economic, etc.) enter relationships of mutual respect despite their differing beliefs (religious, political, etc)". ${ }^{1}$

From the time of its origin, as Modrzhinskaja states ${ }^{2}$ the concept of "cosmopolitanism" has had different interpretations, determined

${ }^{1}$ Anthony Appiah Kwame (1997) "Cosmopolitan Patriots" Critical Enquiry. 23 (3) : 617-39. https://doi.org/10.1086/448846

${ }^{2}$ Modrzhinskaia, E.D. “The Great Soviet Encyclopedia," 2010 3rd Edition (19701979). Entry on Cosmopolitanism. 
by concrete historical conditions. The crisis of the ancient polis (citystate) and the creation of the state of Alexander the Great led to the appearance of various cosmopolitan views. One of them provided the basis for exploitation (Alexander the Great, Marcus Aurelius). The cosmopolitanism of the Cynics Antisthenes and Diogenes of Sinope expressed a negative attitude toward the polis. The Stoics, sought in the cosmopolitan ideal a social form that would create a condition whereby each man could live by a uniform universal law. The cosmopolitanism of the Cyrenaics was expressed in the words ubi bene, ibi patria ("where it is good, there is my fatherland").

During the Renaissance the ideas of world citizenship were directed against feudal fragmentation (Dante and T. Campanella). The abstract, humanist ideal of world citizenship in the era of the Enlightenment expressed the idea of the emancipation of the individual from feudalism. In Germany, in opposition to feudal-particularist "patriotism" and the despotism of the princes, the ideas of world citizenship were developed in a peculiar unity with political ideas by G. E. Lessing, J. W. von Goethe, F. Schiller, I. Kant, and J. G. Fichte. Bourgeois cosmopolitanism reflects the nature of capital, which, like the globalized economy today, strives to where it can expect the greatest profit.

Cosmopolitan ideas have become widespread during the epoch of imperialism, reflecting the objective tendency of capitalism toward internationalization, which operates at the same time as the tendency toward the formation of national states. The cosmopolitan ideas of the creation of a world state or a world federation are also being advanced, at present, by representatives of humanitarian pacifism (as in the proposal to transform the UN into a world state). However, such theories have an obviously Utopian character, since they do not take into account the existence of states with different social systems and the struggles of peoples for national liberation. 
Cosmopolitanism has also been an important area in the study of anthropology. According to Gustavo Lins Ribeiro, "the ambition of anthropological thought-to think humankind in its unicity and variation-has historically placed anthropologists in the midst of cosmopolitan ideologies and utopias. It is difficult to know whether people are attracted to anthropology because they are cosmopolitans or whether abstract notions such as culture(s), society, kinship, and humankind turn them into cosmopolitans."3

Cosmopolitanism is one of the phenomena closely inspected by anthropology. Among Western academic disciplines, anthropology is defined by a wanting to understand the structures of alterity (Krotz2002). Fabian (2012, p.64) ${ }^{4}$ reaffirms this disciplinary singularity, sees alterity as a theoretical concept that was useful to criticize "ideological views of cultural differences," and reasserts its essential epistemological role as the unifying issue of the discipline regardless of where anthropologists are located, in the West or elsewhere. In sum, cosmopolitanism, alterity, and anthropology go hand in hand.

The idea of privilege or normativity of Cosmopolitanism is the focus of my article in which I debate it in view of more or less successful migrations to the countries, migrants consider the most democratic, affluent and open-minded. In this article I will concentrate on the film White (1994) made by Krzysztof Kieslowski, the fragments of which serve as examples of Cosmopolitanism's ambiguities and uncertainties.

Cosmopolitanism and its idealistic approach to equality and following a universal Code of Ethics has been alluded to in Krzysztof Kieslowski 's most famous films from his general philosophical period, that is The Decalogue and The Trilogy including Blue (1993) White (1994) and Red (1994). The Trilogy has sparked my interest because its three

\footnotetext{
${ }^{3}$ Gustavo Lins Ribeiro, World Anthropologies: Anthropological Cosmopolitanisms and Cosmopolitics Annual Review of Anthropology 2014, 43 483-498. p. 484

${ }^{4}$ After Ribeiro, p. 484.
} 
parts forecast great migration movements of the twenty first century and, moreover, the films seem ambivalent about the universal qualities of good will, general goodness and the power of love which keeps people going, no matter what their nationality, economic status and access to power are. Beautifully composed and exuding a feeling of balance and calm, all these films raise questions as to what contexts, national, cultural, and economic the characters in the films have emerged from and how these contexts influence the ways they react to the events in their lives and the way they feel about their identity. At the same time, the films question the intended idealism of the director as they exude ambiguous and complex undercurrents of cosmopolitanism in supposedly uncomplicated notions of freedom, equality and brotherhood which constitute the main themes of the three films.

The film White (1994) is an exceptional work in a continuum of general philosophical films of The Decalogue and The Trilogy (Blue, White and Red), which respectively, provide an illustration of/ commentary on ten commandments in Dekalog (The Decalogue 1989), and, on the three postulates of the French Revolution, freedom, equality and brotherhood. However, unlike Blue and Red, which are of more general, meditative nature, White shows many references to the social situation and the political context in Poland, thus continuing Kieslowski interest in documentary film making and social content films which brought him fame in 1960s and 1970s. His films, Personel (Personnel, 1975), Przypadek (Blind Chance, 1981), Blizna (The Scar 1976), Amator (Camera Buff, 1979) and other, made Kieslowski famous as one of the co-creators of the Polish School of Moral Concern. Following on the social and documentary film leanings the film White, is both symbolic and pitilessly sardonic in its almost documentary reflection on the time of rising capitalism in Poland at the beginning of the 1990s.

The film starts from an image of a big valise travelling majestically on the tarmac at the Warsaw Airport. The valise is big and tattered, old 
fashioned but capacious enough to transport an adult person. As we learn later, this is the mode of transport, Mikolaj helped Karol Karol to use to return to Poland after a short time spent in France. In Poland, Karol fell in love and married Dominique, a French woman, and moved with her to France. After some time, the things got to the worse for the newly wed because Karol was physically unable to consummate the marriage union. Dominique starts the divorce proceedings and when the divorce is announced, Dominique leaves Karol Karol and his valise on the pavement in front of the court in France, and boots him out of his Haidresser's Salon by setting fire to the place and warning of accusing him of arson to the police.

In one sweep then, Dominique deprives Karol of the place to live, to work and to drive a car. She blocks his access to his bank card and thus his funds in the bank and, by starting a fire in his hair salon makes him the perpetrator of fire, thus turning him into a criminal in need of escape. Karol turns into a powerless fugitive, unable to defend himself or to accuse his beloved wife at the French police due to his insufficient knowledge of French. On the one hand, he is still in love with Dominique, on the other hand, he feels humiliated not only by her personal treatment but also by the treatment of the state of France.

In the scene showing the ultimate act of rejection by Dominique, by the state and by society at large, Karol is seen playing his harmonica at the subway station, the ultimate act of humiliation and hopelessness. This is where Mikolaj, a Polish expatriate, meets him and offers him a way out of this situation. He promises that he will help him go back to Poland in return for a favor. Karol arrives in Poland as a fugitive from France and from a law abiding, educated and decent man turns into a shady character who thinks only of revenge.

His feelings of hopelessness and despair seem justified as Karol's professional aspirations and hopes for a better life in France are squashed and he is unceremoniously booted out from France without any chance 
to come back. Seeing no possibility to stay, he wants to return to the country where he was born - slightly provincial, not always lawful, somewhat unkempt, dirty and hopeless. But at the same time, it is the place where the people are full of resourcefulness and deviousness, the country where he hopes to seek revenge on Dominique.

The disrespect Karol Karol experiences in France is shown by the director in subtle tableaus: in one of the sequences only Karol's anonymous legs are shown, and later, before entering the French court, a pigeon releases himself on the lapel of his jacket. In court, the remembered scene of his wedding day in Poland is interjected by the humiliating depositions about the lack of marriage consummation. Joanna Dovalis and John Izod's commentary on this fact go even further. As they say,

"Confronted by Dominique's charge that he has failed to consummate the marriage, Karol proves painfully passive. Impotence pervades every aspect of his life, but he tells the court that things were different when he and his wife met."

Humiliated and unhappy, Karol returns to "the familiar", his own culture. At this point, it is worth asking a question about the value of "familiarity", a negative or positive approach to it and considering it as a subconscious criterion for valuing others. Judith Butler and Paul Gilroy have already devoted considerable attention to this issue in the past.

Judith Butler questions, "at what cost do I establish the familiar as the criterion" for valuing others? ${ }^{6}$ If one values the familiar more than the foreign, what are the consequences? Paul Gilroy offers a possible alternative to this emphasis on familiarity arguing that "methodical

${ }^{5}$ Dovalis Joanna, Izod John Grieving, Therapy, Cinema, and Kieslowski's Trois Couleurs: Blanc "Jung Journal” 2008 vol.2, number 3, pp.39-57, p. 41.

${ }^{6}$ Butler, Judith (2004). Precarious Life. The Powers of Mourning and Violence. New York: Verso, p.38. 
cultivation of a degree of estrangement from one's own culture and history ... might qualify as essential to a cosmopolitan commitment."7

Thus following on Gilroy's thoughts, Karol could have become cosmopolitan by distancing himself from his own "otherness" and consequently embrace a cosmopolitan position. This however also implies the unquestionable acceptance of the culture of France with its imposing legal system which claims the right to unabashedly intrude into the most intimate area of man's life, that is, a sexual potency of a man. The hearing at the French court is so humiliating to Karol that he explodes calling for the right to equality in every life sphere, including the sexual one.

So the aspirations to start a cosmopolitan new life are ruthlessly crushed by the impossibility "to perform" in the consummation of marriage. The idealistic love affair with Dominique started in "the familiar" milieu of Poland turns into "the unfamiliar" ruthlessness of 'superior' France which has presented itself as such in Europe and Poland over many ages and secured its cultural and political influences in the eastern Europe and Russia. This historical context brings to mind another interpretation of Cosmopolitanism that of a snobbish and paternalistic endeavor of early tourists and voyeurs of the $18^{\text {th }}$ and $19^{\text {th }}$ centuries in Europe who regularly travelled to "less developed" countries and voyeuristically acknowledged their ugliness or beauty from a position of a financially well endowed Cosmopolitan gentleman who cannot identify with the people he examines but can voyeuristically appreciate their "difference." Here I would agree with Edward Said and Kwame Anthony Appiah that cosmopolitanism in this case appears to be a new form of colonization whereby the exploitation of the weak consists in the critical aesthetic appreciation of their culture. ${ }^{8}$

7 Gilroy Paul (2004). „The Planet.” After Empire. Multiculture or Postcolonial Melancholia. London: Routledge, p.67.

8 Appiah, Kwame Anthony (2006). "Moral Disagreement". Cosmopolitanism: Ethics in a World of Strangers. Issues of our time (1st ed.). New York: W. W. Norton and Co. pp. $45-68$. 
The valise arrives at the waste dump in Poland as it has been stolen by airport luggage handlers and examined for possible treasures far away from the airport. Despite being seriously beaten by disgruntled luggage handlers, who discover him instead of supposed goods, Karol smiles and sighs with relief when he opens his eyes. "Finally, at home", he says, providing an ironic commentary to a Romantic vision of Maciek's death on a waste dump at the end of the film Ashes and Diamonds (1958), a celebrated post-war film made by Andrzej Wajda. Unlike Maciek, a young survivor of World War II, who famously died on a waste dump at the end of World War II, accidentally shot by Polish soldiers, Karol has survived "the wasteland of history" as the waste dump was usually called by Ashes and Diamonds' critics, albeit without any belongings or money. The only object which has survived the fatal journey with him, is a white bust of a young woman, a kind of romantic embodiment of his love for Dominique which he takes with him into his new life in Poland.

When he arrives at his home in Warsaw, his brother Jurek offers him a job at his hair salon but Karol does not want to be a hairdresser anymore. In a series of ironic tableaux, a signboard of the salon with flashing lights is commented upon by Karol's brother as "a piece of Europe" which, poignantly, is located in an old dilapidated building somewhere at the outskirts of Warsaw, the capital of Poland.

Karol is looking for a way to make money fast, as millions of people did in a rising capitalism in Poland at that time. The film which Stanislaw Zawislinski calls "komediogroteska"

był nieco ironicznym, zdystansowanym spojrzeniem na odradzający się polski kapitalizm. Wielu rodakom reżysera perypetie, których doswiadcza Karol, bohater filmu, wydawaly się nieprawdopodobne, a przedstawione realia zanadto oderwane od rzeczywistości. To paradoksalne, bo przecież fabula pelna jest sytuacji wziętych prosto z zycia, prosto $z$ gazety (comedy grotesque offered an ironic, distanced look at the new Polish capitalism. Many compatriots of Kieslowski considered Karol's 
misfortunes improbable while Polish reality too removed from real documented life occurrences in Poland. Kieslowski considers this comment paradoxical because the film plot is full of the situations taken directly from documented events described in everyday newspapers - transl. Janina Falkowska). ${ }^{9}$

Karol starts from a low-rank position, that of a security guard at the Currency Exchange in a local flea market, but thanks to his resourcefulness and determination, he climbs the social ladder very fast. By overhearing a conversation between his boss and his collaborator in a car, he gets an unmatched opportunity to make money by buying field plots from unsuspecting farmers. In the early nineties, Poland experienced an upsurge in construction and road building in the entire country, but most specifically near Warsaw. Highways, warehouses, factory buildings were usually put up in small villages or hamlets. The owners of field plots were recompensed by buyers for a fraction of the price such a plot would reach at the official sale, so a number of prevaricators fooled the small owners into selling their land to them for a small amount of money. In a surprising, unromantic turn, Karol turns from a decent, educated man into a shady businessman engaged in dealing and wheeling with criminals.

Suddenly Mikolaj turns up at the Hairdresser's Salon and asks Karol to keep his promise he made back in Paris to do something for Mikolaj to reciprocate for helping him escape from France. Karol meets Mikolaj at the main Warsaw railway station at the end of the railway platform, and he learns there that he has to help Mikolaj commit suicide. Mikolaj is determined to die without giving any reason for this tragic decision, so with a heavy heart Karol pretends to shoot him, alas with a blank instead of a real bullet. Almost on the brink of death, Mikolaj recovers from the shock and does not want to die any more.

${ }^{9}$ Zawiśliński Stanisław, Kuśmierczyk Seweryn. Ważne żeby iść... Skorpion 2005. p. 350 . 
From that moment, Karol and Mikolaj know that they can depend on each other, which Karol takes advantage of by starting a joint partnership with him. The small company spectacularly grows, Karol builds a residence for himself and engages in all kinds of ImportExport deals. Kieslowski talking about the film mentions the fact that such spectacular careers were not out of line at the beginning of the transformation period in Poland, the observations he made based on real-life stories reported on Polish television and on the radio. ${ }^{10}$

The only person Karol misses is Dominique who does not respond to his calls or wants anything to do with him. Karol obsessively learns French in hope to gain her back and longingly admires the bust of the young female which has become a symbol of unfulfilled morbid love, the one he has brought with him from France. In fact, the trait of love mixed with death is sensed from the very beginning of the film and saturates its almost every sequence. The death trait is present in an unusual friendship between a mysterious Mikolaj and helpless Karol, as it is present in the whiteness of the reappearing wedding scene and most profound in the white bust of the woman. Finally, death is the only way to lure Dominique back to Poland and to Karol, dead or alive. By faking his own death and making Dominique the only inheritor of his vast fortune, he forces her to travel to Poland and appear at his funeral.

When he watches her at his grave in which the body of an unknown deceased person from Russia is buried, he realizes that she is sad and crying. He cannot approach her and give her a hug because he is already "dead" and non-existent both as a human being and as an entrepreneur, a legal person. Only Mikolaj and Jurek know his plans and collaborate on executing an improbable act of revenge on Dominique.

The act of revenge culminates in the room of the hotel where Dominique stays after seeing her deceased husband's lawyer. When she

${ }^{10}$ After Zwiśliński in his interview with Krzysztof Kieślowski included in the formerly quoted book, 352 . 
switches on the light, she recognizes Karol, well and alive and naked in her hotel bedroom. She is stunned but strangely moved and loving. The love act consummated in the hotel room is on Karol's terms: he is no longer an aspiring cosmopolitan but rather a provincial nationalist closely connected to the land he comes from. His equality comes from the space of the country which he considers equal to the superior France, making an act of lovemaking and the consummation of marriage an ironic statement on the interpretation of nationalism, cosmopolitanism, and, cultural and economic aspirations of migrants.

The revenge act comes to completion when Karol disappears from the hotel room the next day and Dominique faces Polish police accusing her of plotting Karol's murder in order to get access to his considerable fortune in Poland. Her explanations are not satisfactory because nobody believes them or wants to believe them for two reasons: first, the police assume that Karol is really dead and her plotting to kill him scenario seems probable; second and more probable, the whole visit by the police unit just after the funeral has been arranged by Karol and Mikolaj anyway, in order to frame Dominique for Karol's death.

The final scene is a bitter commentary on death, the power of love, equality and nationalism. Karol visits Dominique in prison, or, rather, looks at her longingly from the prison yard. Dominique is framed by the soft halo of light in her prison cell. She tries to communicate her love using the sign language and promises to stay married to Karol when she leaves the prison.

Somehow, this clear communication does not seem convincing to Karol who smiles but with a bitter grimace on his face. His lips seem to curl like the Batman's cruel face in a promise of more cruelty on his part in the future rather than in an expression of unconditional love for Dominique. My cynical interpretation comes from Jurek's, Karol's brother report on a meeting with Karol's lawyer who predicts a long legal battle for the release of Dominique from prison. Somehow Karol 
does not seem particularly unhappy about this prediction. After all, he has his object of infatuation/obsession frozen, dead, unable to leave her prison cell, but waiting longingly for Karol as her only savior. Both Dominique and Karol are crucified by their love/obsession and cruelty, they are both dead already and both turned into marble busts; Karol on his grave and Dominique in her cell.

As Dovalis and Izod interpret this last scene:

True, he knows now that he loves her dearly. True, he weeps copiously when Dominique makes her appeal. True too, he smiles back at her; but just before the image fades for the last time, he averts his gaze and resolve braces his lips. Instead of giving in to his desire to free her, he seems likely to balance it against the recognition that to do so would be premature. He seems to know that she must feel the strength of his new sense of self, just as he was injured by hers, if they are more fully to understand themselves and each other. Thus, White ends with hope, but no denouement. That fits not only the state of the couple's relationship but also that of the collective. In resisting any temptation to round off White with a fairy-tale ending, Kieslowski has kept faith with the then political circumstances of Poland. In the film it remains a nation still in transition from the Communism it had abandoned only five years earlier in favour of a corrupt and corrupting free market - a period when Poles had hopes but not yet the certainty of entering the European Union. A denouement postponed until the conclusion of Red. ${ }^{11}$

This last remark refers to the final scene in Red where all the protagonists of the Trilogy emerge from the drowning ferry miraculously saved from death. Among them are Julie and Olivier (Blue) Karol Karol and Dominique (White) and Valentine (Red).

At this point we could ask whether the drive to equality which Cosmopolitanism takes for granted has to end in real or imagined death related to one's national identity, whereby, as Chenchen Zhang postulates, cosmopolitanism mirrors contemporary trends of cosmopolitan

${ }^{11}$ Dovalis, Izod , p. 55. 
thought which are, more often than not, still locked in homogenous, solid, nationalist space. So, in reconsidering Cosmopolitanism it would be advisable to consider nationalism anew and, as in White, see it as an important factor in the debate of Cosmopolitanism, migration and globalization.

As Zhang states,

This revisiting is driven by an observation of the tendency in nationalism studies where universalistic models of nationalism are posited side by side with the persistence of the "incommensurability of cultures" and of "identities" (Sontag 2002:346). This is to say, researchers either label nationalisms in terms of universalistic models (e.g. "liberal nationalism" versus "non-liberal nationalism", "political nationalism" versus "cultural nationalism", "civic nationalism" versus "ethnic nationalism", and even "Western nationalism" versus "Eastern nationalism"), or get caught into the narrative of cultural identities. Treating Liang's writing on nation and nationalism beyond the framework of "Chinese nationalism" in which it has been usually contextualised, I assume that nationalism, as a "universal model against universalism" (Delannoi 1999:77), is one of the defining components of political modernity, understood here as the conceptual and institutional construction of the territorially defined nation-state as the exclusive mediator between claims of universality and those of difference (Walker 1993)". ${ }^{12}$

In other words, Karol Karol could become more aware of cosmopolitan disposition only when he regained his national pride and a semblance of financial equality on par with middle or even upper middle class in France. To raise above "impotence" he had to undergo the process of acculturation to the culture of his beloved and recover his pride undisputedly linked to his own country. At the end of The Trilogy in Red, Karol Karol is seen with Dominique happy and on equal footing

${ }^{12}$ Zhang, Ch. Situated Interpretations of Nationalism, Imperialism, and Cosmopolitanism: Revisiting the Writings of Liang in the Encounter Between Worlds" Journal of Historical Sociology” 2014 Vol. 27 No. 3. https://doi.org/10.1111/johs.12058 
with her. Here Kieslowski's idealistic presentation infers that love only saves Dominique and Karol Karol's union. The truth is that in order to reclaim Dominique Karol Karol had to undergo his own transformation to become equal to Dominique and the world she comes from. The migration from Poland and then back to Poland again facilitates the process of transformation, and, at the end of the film we see Karol Karol and Dominique saved from the clutches of death.

\section{BIBLIOGRAPHY}

Appiah, K.A. "Kindness to Strangers". Cosmopolitanism: Ethics in a World of Strangers. Issues of our time (1st ed.). New York 2006. Pp. 155-174.

Appiah, K.A. "Moral Disagreement". Cosmopolitanism: Ethics in a World of Strangers. Issues of our time (1st ed.). New York 2006. Pp. 45-68.

Appiah K.A. "Cosmopolitan Patriots" Critical Enquiry. 23 (3) 1997. Pp. 617-39. https://doi.org/10.1086/448846

Butler, J. Precarious Life. The Powers of Mourning and Violence. Verso, New York 2004.

Dovalis J., Grieving J.I. Therapy, Cinema, and Kieslowski's Trois Couleurs: Blanc "Jung Journal" vol.2, number 3, 2008. Pp. 39-57. https://doi.org/10.1525/jung.2008.2.3.39

Gilroy P. „The Planet.” After Empire. Multiculture or Postcolonial Melancholia. Routledge, London 2004. https://doi.org/10.4324/9780203482810

Haltof M. Polish National Cinema, Nowy Jork, Oxford 2002.

Modrzhinskaia, E.D.” The Great Soviet Encyclopedia," 3rd Edition (1970-1979). Entry on Cosmopolitanism. 2010.

Ribeiro G.L. World Anthropologies: Anthropological Cosmopolitanisms and Cosmopolitics, "The Annual Review of Anhropology" $2014 \mathrm{nr} 43$. Pp. 483-98. https://doi.org/10.1146/annurev-anthro-102313-030139 
Said, E. Orientalism, Vintage Books, New York 1978.

Zawiśliński S., Kuśmierczyk S. Ważne żeby iśćc.. Skorpion, Izabelin 2005.

Zhang, Ch. Situated Interpretations of Nationalism, Imperialism, and Cosmopolitanism: Revisiting the Writings of Liang in the Encounter Between Worlds "Journal of Historical Sociology" Vol. 27 No. 3. 2014. Pp. 343-360. https://doi.org/10.1111/johs.12058. 